\title{
Design and Analysis of Compression Low Profile Load Cells
}

\author{
Ming-Hsiung $\mathrm{Ho}^{1, \mathrm{a}^{*}}$, Pin-Ning Wang ${ }^{2, \mathrm{~b}}$, Jung-Peng Yeh ${ }^{1, \mathrm{c}}$ and Bing-Han $\mathrm{Wu}^{3, \mathrm{a}}$ \\ ${ }^{1}$ Department of Mechanical Engineering, Nanya Institute of Technology, Jhongli, 32054, Taiwan, \\ R.O.C.
}

${ }^{2}$ Department of Material and Fiber, Nanya Institute of Technology, Jhongli, 32054, Taiwan, R.O.C.

${ }^{3}$ Department of Mechanical Engineering, Taipei City University of Science and Technology, Beitou, 11202, Taiwan, R.O.C.

amorrisho@nanya.edu.tw, bpnwang@nanya.edu.tw, cyjp@nanya.edu.tw

Keywords: Load cell, Stress analysis, Strain gage, Compression, Bending beam.

Abstract. The purpose of this study is to investigate the stress, strain and deformation distribution of the geometrical shape of the low profile load cell and the stress and strain of the curved beams under the rated load and overload conditions and to evaluate the influence of the stress and strain on the design of the surrounding beams. In the stress analysis, the L-type under an overload condition, the stress reaches $837.8 \mathrm{MPa}$ has exceeded the material yielding stress value $710 \mathrm{MPa}$. The L-type design of the load cell $\mathrm{R}$ guide angle for the stress concentration slow down has obvious help. The C-type design of the curved beams on the back of the arc, you can make the stress distribution more uniform, will not focus on local stress. In the strain analysis results show that the L-type design under the load, the end of the $\mathrm{R}$ angle with or without the impact. The $\mathrm{C}$-type design of the bending beams about the L-type maximum strain decreased by about $20 \%$ of the strain. The maximum strain of the L-type occurs at the discontinuous surface of the bending beam and the outer ring and is suitable for pasting the strain gauge. The C-type load cell in the adhesive surface of the plane has a uniform strain, suitable for the strain gauge affixed to the inner ring or outer ring and beam contact position.

\section{Introduction}

Generally speaking, the sensor is a device to convert energy; the sensor is often used to convert mechanical energy into the electronic signal device. The strain gauge uses a strain gauge array to measure the degree of deformation of the structural member and convert it into an electronic signal. There are a variety of different types of the load cell, and with different design methods; but the most commonly used load cell is the strain gauge type load cell. So the application of load cell products in medical equipment, engineering machinery, chemical fiber and other needs of the measurement and control of various occasions. In recent years, injection molding machine manufacturers to develop full electric injection molding machine, the production of high-quality, high-precision products such as medical equipment, electronic products. In the injection mold process, the injecting pressure, holding the pressure of the control molding parameters must be under control. The use of load cell as the force feedback sensor is very important.

Frederick [1] designed a load cell patent for vehicle component to measure loading in proving ground. Piskorowski [2] had studied a new method for dynamic compensation of the load cell response using a linear time-varying continuous-time filter. The results verifying the effectiveness of the proposed filter were presented and compared to the traditional time-invariant configuration. Joo [3] had design and evaluation compact six-component load cell. The load cell could measure three components of force, moment and torque. They determined the location of strain gauges using finite element analysis and then connected the strain gauges so that bridge circuits with four strain gauges would be balanced. Alam [4] used using a genetic algorithm and multi-objective optimization methods to the structural design of double end beam load cell. Two design variables were used to minimize the structural mass, to maximize the structural strength, and to maximize the level of measurement accuracy. Based on the optimal results, the weight reduction of the structure was successfully achieved of about $8.6 \%$. 
The sensitivity of the strain gauge is related to the geometry design of the load cell. Therefore, this study focuses on the stress and deformation analysis of the geometric design of compression load cell and discusses the sensitivity analysis of geometric shape design and strain data.

\section{Methods}

This study used the analysis method, refer to the current injection molding machine manufacturers commonly used load cell specifications to rated load $60 \mathrm{kN}$, the design of the basic dimensions, fixed holes. Respectively, for geometric shape design and analysis works, the processes are as follows:

Before FEA analysis, the load cell models were designed by using SolidWorks 3D CAD software, then transform models for FEA analysis. Establish an analysis model: According to the load cell requirements size and rated capacity requirements, the original dimensions of the three models were designed in SolidWorks software. The design of the bending beam types in the models was based on the current design and new design. The analyses were focused on the models stresses concentration areas and the strain gage paste position.

Analysis models. The alloy steel material used in the analysis model is SNCM439, which is utilized in the screw, gear, shaft parts, vehicle parts and various high strength structural steel. The detailed material properties used in the analysis are shown in Table 1.

Table 1. The material properties for analysis.

\begin{tabular}{||c|c|c|c|c||}
\hline \hline Designation & \multicolumn{4}{|c||}{ Properties } \\
\hline Grade & $\begin{array}{c}\text { Young Modulus } \\
\left(\mathrm{N} / \mathrm{mm}^{2}\right)\end{array}$ & $\begin{array}{c}\text { Yield Stress } \\
\left(\mathrm{N} / \mathrm{mm}^{2}\right)\end{array}$ & $\begin{array}{c}\text { Tensile Strength } \\
\left(\mathrm{N} / \mathrm{mm}^{2}\right)\end{array}$ & $\begin{array}{c}\text { Poisson } \\
\text { Ratio }\end{array}$ \\
\hline $\begin{array}{c}\text { SNCM 439 } \\
\text { (High Tensile) }\end{array}$ & 205,000 & $\geqq 710$ & $\geqq 1110$ & 0.32 \\
\hline
\end{tabular}

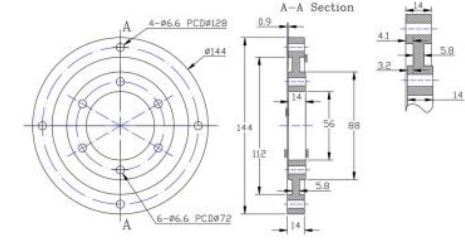

Figure 1. The L-type R0 load cell.

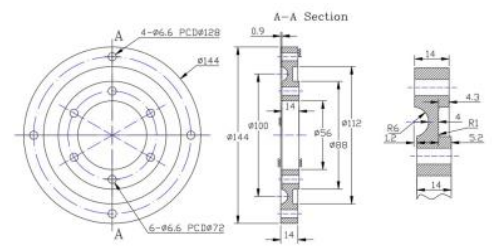

Figure 3. The C-type load cell.

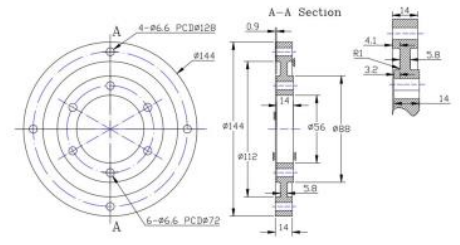

Figure 2. The L-type R1 load cell.

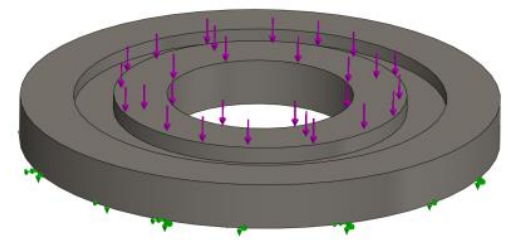

Figure 4. The boundary conditions for analysis

Table 2. The stress, strain and deformation analysis results.

\begin{tabular}{|c|c|c|c|c|}
\hline \multirow{2}{*}{$\begin{array}{c}\text { Loadcell } \\
\text { Types }\end{array}$} & $\begin{array}{c}\text { Loading } \\
\text { condition }\end{array}$ & $\begin{array}{c}\text { Maximum } \\
\text { stress }\end{array}$ & $\begin{array}{c}\text { Maximum } \\
\text { deformation }\end{array}$ & $\begin{array}{c}\text { Maximum } \\
\text { strain }\end{array}$ \\
\cline { 2 - 5 } & $\mathrm{kN}$ & $\mathrm{MPa}$ & $\mathrm{mm}$ & $\mu \varepsilon$ \\
\hline \multirow{2}{*}{ L-Type R0 } & $60 \mathrm{kN}$ & 558.5 & 0.1085 & 1335 \\
\cline { 2 - 5 } & $90 \mathrm{kN}$ & 837.8 & 0.1627 & 2002 \\
\hline \multirow{2}{*}{ L-Type R1 } & $60 \mathrm{kN}$ & 454.9 & 0.1049 & 1400 \\
\cline { 2 - 5 } & $90 \mathrm{kN}$ & 682.4 & 0.1574 & 2100 \\
\hline \multirow{2}{*}{ C- Type } & $60 \mathrm{kN}$ & 349.7 & 0.1185 & 1157 \\
\cline { 2 - 5 } & $90 \mathrm{kN}$ & 524.6 & 0.1778 & 1735 \\
\hline
\end{tabular}


The load cell models designed in this study are a bending beam type, and the middle hole is suitable for the feed pipe passing through the injection molding machine. Load cell inner ring holes connected with the injection mold, and load cell lateral ring holes connected injection machine body. When the molding machine is working, the bending beam located between the inner and outer connecting rings is the position of the bearing force.

The dimensions of three load cell types for analysis were shown in Fig. 1 3. In Fig. 1, the bending beam of the internal and external ring edge of the critical design of the machining processing chamfer radius of $0 \mathrm{~mm}$ (R0). Fig. 2 for the actual machining processing of the state, between the internal and external ring corner, the bending beam was machined chamfer radius 1 mm (R1). In Fig. 3 the load cell model's the inner and outer ring with a curved bending beam and machined chamfer radius $1 \mathrm{~mm}(\mathrm{R} 1)$. The bending beam's one side with the flat surface for the strain gauge, and the other side was machined by the curve shape. The R0 condition was used for analysis, to understand the most stringent design state.

The boundary conditions of load cell were outer ring fixed, and the inner ring applied loading. Three types of load cell rated load of $60 \mathrm{kN}$ and evaluated the overload by $50 \%$. That is mean the load cell under $90 \mathrm{kN}$ loading condition. Fig. 4 shows the boundary conditions used for the analysis. During the loading simulation of the load cells, the stress and strain distribution were recorded and analyzed. And the stress and strain distributions of the bending beam area were observed.

\section{Results and Discussions}

For the design of the three kinds of load cell geometric modeling, L-type with no chamfer, L-type with chamfer and C-type load cell analysis results, listed in Table 2.

Stress Analysis. In Table 2, the stress analysis result of the L-type load cell with zero chamfer radius showed that the maximum stress was $837.8 \mathrm{MPa}$ at the $90 \mathrm{kN}$ overload condition. This stress had exceeded the material yielding stress value of $710 \mathrm{MPa}$. Apparently, load cell bending beam edge connected the inner and outer ring with the design of zero chamfer radius cannot withstand the overload condition. But the rest of the load cell type in the $60 \mathrm{kN}$ and $90 \mathrm{kN}$ loading conditions can be under the yielding stress. The C-type bending beam load cell maximum stress is $349.7 \mathrm{MPa}$, and the safety factor is 2 , for the three design load cell of the minimum stress. General machining will have the chamfer radius, but because of the need to paste the strain gauge, so rounded corner radius is not too large, to increase the sensitivity of strain gauge measurement.

Compare the impact of rounded corners of bending beam between inner and outer ring. From Fig. 5 with zero chamfer radius and Fig. 6 with chamfer R1 under $90 \mathrm{kN}$ loading condition, the von Mises stress results were showed that the R1 chamfer could cause stress concentration to be eliminated, avoiding high stress generation in geometrically discontinuous locations and avoiding high stress in the interior of the material.

In Fig. 7, The C-type load cell with bending beam with a curved surface on the back, it can make the stress distribution more uniform; would not concentrate stress on the local area.

Strain Analysis. Because the location of the bending beam needs to paste the strain gauge, so the amount of strain value generated by the load and geometry will affect the load cell sensitivity performance. If the load cell strain too small under the small forces condition, the strain gage would have the poor response; or the load cell produced strain too large, will make load cell and strain gauge too early damage.

From Table 2 and Fig. 8-9, the L-type load cell in the $60 \mathrm{kN}$ loading condition had the maximum strain between $1400 \sim 1335 \mu \varepsilon$, and in $90 \mathrm{kN}$ loading, the condition had the maximum strain between $2000 \sim 2100 \mu \varepsilon$. It is clear that the rounded corners of the bending beam between inner and outer ring would not be affected. As showed in Fig. 8 and 9, the maximum strain of the L-type occurs at the discontinuous surface of the bending beam and the outer ring, and it is suitable for pasting the strain gauge. The strain value of the C-type load cell bending beam was reduced by about 200 to $350 \mu \varepsilon$ on the maximum strain of the L-type showed in Fig. 10. The C-type load cell was reduced the amount of strain by about $20 \%$ on the L-type load cell. 


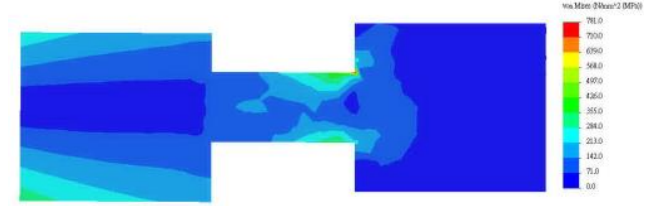

Figure 5. The von Miser stress of L-type R0.

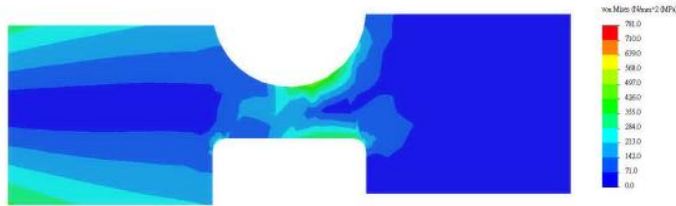

Figure 7. The von Miser stress of C-type 1.

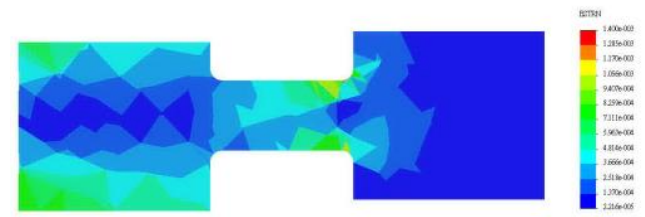

Figure 9. The strain of L-type R1 under 60 kN. Figure 10. The strain of C-type under $60 \mathrm{kN}$.

\section{Conclusion}

The results of load cell analysis can be summarized as follows:

1. In the stress analysis results section, the L-type under $90 \mathrm{kN}$ overload conditions, the maximum stress $837.8 \mathrm{MPa}$ has exceeded the material yielding stress value. The L-type load cell chamfer radius $\mathrm{R}$ for the stress concentration slowness has obvious help, although the practice of processing will not have R0 state. The C-type load cell with a curved surface on the beam back, it can make the stress distribution more uniform.

2. L-type in the loading conditions, the chamfer $\mathrm{R}$ radius had no effect on strain distribution. The bending beam of the $\mathrm{C}$-type had a strain reduction of about $20 \%$ about the maximum strain of the L-type. The maximum strain of the L-type occurred at the discontinuous surface of the bending beam and the outer ring and is suitable for pasting the strain gauge. The C-type in the adhesive surface of the plane had a uniform strain, suitable for the strain gauge posted to the inner ring or outer ring and beam contact position.

3. The three design models will be compared to the design evaluation to provide subsequent load cell design and application reference.

\section{Acknowledgement}

In this paper, the research was sponsored by the Ministry of Science and Technology (Project No. MOST 105-2221-E-253-005)

\section{References}

[1] P.H. Frederick, J.D. Davis, U.S. Patent 6,351,998 B1. (2002)

[2] J. Piskorowski, T. Barcinski: Mech. Sys. Sig. Proc., Vol. 22, ( 2008), p.1694

[3] J.W Joo, K.S Na, and D.I Kang: Measurement, Vol. 32 (2002), p. 125

[4] H.S. Alam, Bahrudin and D. Soetraprawata: Optics. Micro. Elec-Mech. Sys. Inform. Tech. (2015), p. 52 